\title{
Housing Qualities Characteristics towards Relationship on House Prices
}

\author{
Muhamad Hilmi Mohamad @ Masri ${ }^{1}$, Abdul Hadi Nawawi ${ }^{1}$, \\ Edie Ezwan Mohd Safian², Ahmad Fawwaz Ahmad Saleh¹
}

1Department of Postgraduate Studies, Faculty of Architecture, Planning and Surveying, Universiti Teknologi MARA (UiTM), 40450 Shah Alam, Selangor, Malaysia 2Universiti Tun Hussein Onn Malaysia, 86400 Batu Pahat, Johor, Malaysia

hilmimasri@gmail.com, abdul274@salam.uitm.edu.my, edieezwan@yahoo.com, ahmadfawwaz91@yahoo.com

\begin{abstract}
The research was conducted in order to obtain measurement for characteristics quality of houses in Malaysia. The aim of this research was to produce the results needed for the relationship between house qualities and house prices. The methodology used in this research was primarily by AHP and Regression Analysis conducted between the characteristics and house prices. Data collection gathered through a sampling of landed terrace houses in the Klang district was incorporated for this. The results from the research showed several significant findings that can improve quality of life for targeted households

Keywords: House Quality; Regression; GIS; AHP

eISSN 2398-4279 @ 2019. The Authors. Published for AMER ABRA cE-Bs by e-International Publishing House, Ltd., UK. This is an open access article under the CC BY-NC-ND license (http://creativecommons.org/licenses/bync-nd/4.0/). Peer-review under responsibility of AMER (Association of Malaysian Environment-Behaviour Researchers), ABRA (Association of Behavioural Researchers on Asians) and CE-Bs (Centre for EnvironmentBehaviour Studies), Faculty of Architecture, Planning \& Surveying, Universiti Teknologi MARA, Malaysia.

https://doi.org/10.21834/ajqol.v4i15.183
\end{abstract}




\subsection{Introduction}

The housing qualities were part of houses characteristics that seen towards helping higher quality of living by occupants. Occupants of houses were familiar with their own houses qualities, but improvements that were substantial and can be made was needed to be quantified through empirical evidence. The researcher in this study will then conduct the problem statements discussion and also literature reviews resulting that house qualities required to be identified and measured on the relationship between house prices. Through the help of Analytic Hierarchy Process and Geo-Information System, weightages of houses characteristics qualities can be determined. AHP and GIS help in the determination of the weightages and generate faster solutions to achieve them. These weightages can be subsequently utilized to achieve the aim and objectives of the study. The aim of this study was to come up with significant results of the relationship between house qualities and house prices. The first objective to achieve the aim was to produce the weightage of the house characteristics qualities. As for the second objective, it was to measure the significant relationship between house characteristics qualities and houses prices. The methodology involved was by applying the AHP and conducting Regression Analysis between the characteristics and house prices. For this study, ten residential areas were sampled, and a number of fifty houses was measured on its relationship. The residential areas consisting of the ten residential areas were located in the district of Klang, Selangor, and was used as representation for houses in the Klang Valley. The houses focused on this study will focus on landed houses and utilises single and double-storey terrace houses. Regression analysis was chosen to analyse the weightages as it can help to produce significant findings for the study. The findings will be expected to contribute towards areas of characteristics qualities needed to increase the quality of life of the house's occupants. The implications projected were that houses offered afterwards will be pinpointed towards areas specific to improve the whole livelihood of the occupants.

\subsection{Literature Review}

\subsection{Determination factor of Characteristics Qualities of Houses with Prices}

From the introduction outlined earlier, the most important part of the study were the house characteristics qualities. From the research aim, there needed to have results of the relationship between house qualities and house prices that were significant. For this to be conducted, the achievement of the outlined objectives were crucial. In this study, a holistic discussion on other and previous research must be done to give fill in the research gaps derived that was the relationship between house characteristics qualities and house prices. From this, the researcher the produce the needed findings that were significant according to the aim and objectives.

The researcher also will discuss relating towards the relationship between the house characteristics qualities and the houses prices. In this sense, their identification will be conducted one by one and measured based on their significance relationship afterwards. This relationship between the variables were needed to help contribute towards livelihoods 
of occupants the housing industry key stakeholders (Karim, 2012). Housing characteristics also showed that mismatches between them and prices need to be addressed (A. F. A. Saleh, Hwa, \& Majid, 2016; A. F. Saleh, Hwa, Ab Majid, \& Mohamad@Masri, 2017).This condition also helps as part of the quality of life as houses provided with suitable characteristics qualities give better attributes towards comfort, satisfaction and security.

Through the application of characteristics qualities of houses, stakeholders from various industries can make investments in the local and even international housing markets. (Kim, Han, \& O'Connor, 2015). The researcher believes that the investors have the ability in making good decision for purchasing and also making investments in the housing market. The characteristics qualities of houses also can be interpreted towards providing the buyer or investor as market holders, rather than the usual place to live, eat and sleep (Ball, 2015).

Housing projects that have characteristics qualities that were up to date also have become suitable attraction for investors nowadays. Attractive and upcoming characteristics such as Green Building theme of houses also have become a popular element amongst developer, and also prospective house buyers as the functions of houses have transformed from living to become investment portfolios in today's property market (Li, Guo, You, \& Hui, 2016). The space of urban residential area was also seen to become increasingly important in today's residential property offering (Omar, Omar, Othman, \& Yusoff, 2016).Besides that, house investors also consider the attractiveness of theses houses as main factor to buy. Besides that, house buyers also wants maximise their gains from money forked out into buying these houses.. Buying houses needed high capitals, therefore, its expected that the buyers receive the best output from their investment and also obtain appreciation their in future values (Adeoye, 2016).

The aspects of house characteristics were complex and tedious, but the researcher has narrowed down this discussion through earlier and previous researches conducted. For this study, the researcher has outlined the characteristics qualities needed sutiable to be implemented as part of the measurement of the characteristics qualities of the house and house prices.

Here, the researcher has compiled several previous research conducted earlier that can help determine the characteristics quality be implemented afterwards. Khoiry, Tawil, Hamzah, Ani, \& Sood, (2012), Ramzi, Hussain, Tukiman, \& Zen, (2014) and Zahirovichherbert \& Gibler, (2014) have provided valuable insights towards characteristics qualities and the researcher has summed up that there were eight main characteristics that determine and affects the house prices. The characteristics were functionality, presentation, environment, amenities, community, management, location and access.

The characteristics qualities of houses outlined earlier will, therefore, be integrated for their relationship measurement with the house prices. The house prices themselves will be extracted from the sample areas that will be outlined afterwards in the research process.

\subsection{Background Literature on the Relationship between House Characteristic's Qualities with House Prices}

From the previous topic discussions, the researcher has gather several previous research that can help portray the houses characteristics qualities relationships with house prices. This 
statement also needs to be supported by empirical evidence and the upcoming measurements to explain their significance. This research also wants to look at the issues and problems that were available from characteristics qualities and their subsequent effects. In the local context of Malaysia, they were previous researchers conducted on the characteristics qualities aspect, but most of them focus more towards building characteristics only (Safian, Nawawi, \& Sipan, 2014). This argument was needed to be supplemented with other opinions of researchers that states building characteristics must also be included together by other elements such were locational and also neighbourhood aspects (Masri, Nawawi, Safian, \& Saleh, 2017). This statement, therefore, can be integrated into defining the characteristics qualities needed to measure the relationship between house prices.

In the more broad and globalised context, other elements such as green technology, and even sustainability complements towards the building of new township and also new housing developments can be included together the measurement of housing qualities characteristics. Other studies conducted by Jucevičius et al., (2014) also showed green technology and sustainability can help in providing for better quality housing and has the long-term effects towards housing prices in the property market. This statement was also supported by Elshater, (2012) that showed houses with good characteristics qualities can improve quality of life thus the houses were considered more attractive towards potential house buyers.

Another research by Hui et al., (2007) also showed that quality given of houses and their neighbourhood area has a prevalent relationship regarding the property market and also the house prices. These previous researches thus help to support the researcher in stating that characteristics qualities were needed to be measured in relation towards house prices. Another statement supporting this idea was by Panduro \& Veie, (2013) which showed that housing characteristics outlined and as small as the external environment of the area can produce significant influences towards house prices. All this attributes needed to be measured as they can help determined a holistics approach in producing better house prices in the future.

The literature outlined above shows that housing characteristics and their relationship towards house prices were needed to be identified whether theoretically or empirically. In Malaysia, there were a limited amount of similar research conducted, thus providing a research gap required to be filled by the researcher. Through this condition, it's vital for the researcher to achieve the first outlined objective of producing the weightage of the house characteristics qualities. The second objective to be achieved were a direct linkage to the first objective that was to measure significant relationship between house characteristics qualities and houses prices. The next topic will discuss on the methodology needed to be outlined to achieve these objectives thus subsequently achieve the overall aim of the research that was to come up with significant results of the relationship between house qualities and house prices.

\subsection{Weightage of Importance for Building, Locational, and Neighbourhood Characteristics of Houses}

To achieve the outline aim and objectives, weightage of importance for characteristics of 
houses were needed to be measured. The researcher in this case has employed the help of the Analytic Hierarchy Process or AHP to make better decision relating towards the houses quality characteristics. The usage of AHP is measurement tools that can yield prominent results through the systematic measurement technique that it encompasses especially in selecting, ranking and justifying characteristics, and most importantly it has the concept of hierarchical structure analysis (L. Abdullah, Jaafar, \& Taib, 2013).

Through the implementation of AHP, it helps to put approaches of both qualitative and quantitative into a single empirical question, through compilation towards an understanding of context (Dinarvandi, Jafari, Mohamadi, \& Hosseini, 2014). The systematic hierarchy of AHP will produce the needed weightage gained from observation forms that help to retrieved consistent answers from prospective respondents (Safian \& Nawawi, 2013).

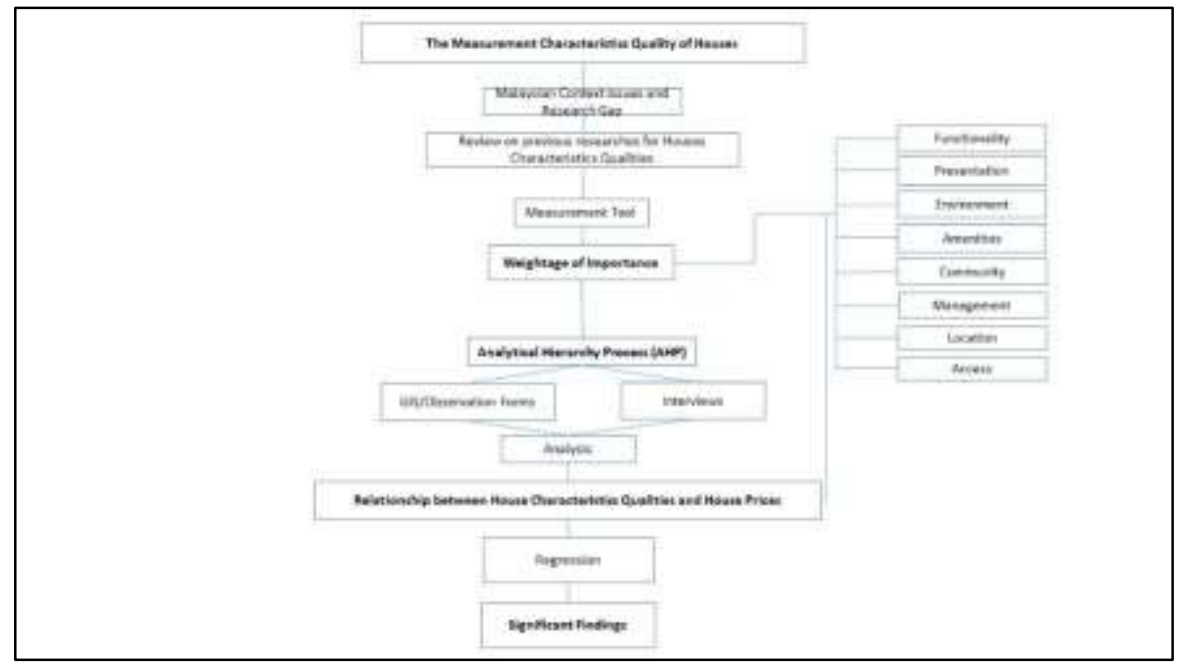

Figure 1: Theoretical Framework for the Measurement of Characteristics Quality of Houses

Based on the research done by Tobergte \& Curtis, (2013), AHP can be distributed towards three key principles which were comparative judgements, synthesis of interest and decomposition. The measurement method encompasses the theory of discussing characteristics involved in research and looked at primarily towards their quantity and their differences involved. The method for AHP showed how decision theory were discussed in high versalitiy, and showed the process which pointed out problems can be solved (Erbıyık, Özcan, \& Karaboğa, 2012). For this research, the researcher has decided to apply AHP, particularly on the measurement of importance towards the houses characteristics qualities. As shown earlier in the research, the variables being used in were functionality, presentation, environment, amenities, community, management, location and access. The variables outlined were important to be compared with one another so that each characteristic of 
houses can get the weightage of importance.

Based on the discussion above, the researcher also has found some limitations relating towards the implementation of AHP. The main issue towards the usage and implementation of AHP is to get suitable respondents that can give weightage importance for characteristic's quality of houses. The studies conducted by Safian \& Nawawi, (2013), Dinarvandi et al., (2014), Agarwal, Patil, \& Mehar, (2013), and Erbıyık et al., (2012) showed that they have chosen tenants, owners and also property users as respondents in achieving the goal of producing importance of each characteristic of houses. Other research conducted by Ho et al., (2005), Pekkonen, Du, Skon, Raatikainen, \& Haverinen-Shaughnessy, (2015), Mulliner, Smallbone, \& Maliene, (2013) and Khoiry et al., (2012) has shown that they have preferences to choose users, occupants, and owners of houses in their research as they were the residents of the houses and had the highest information relating towards their properties. Based on the actions from previous researchers, the researcher has concluded that the occupants will the most suitable respondents in the measurement of weightage of importance towards characteristics of houses. Their familiarity and knowledge of their own houses will become a great addition of knowledge towards the study.

\subsection{Methodology}

\subsection{Quantitative Method}

\subsubsection{AHP}

As described earlier, the researcher has decided to sampled from residential areas in the Klang district, State of Selangor. This consists of 50 houses together with 50 respondents sample to satisfy the requirement of AHP. From the samples gathered, the researcher will then incorporate the elements of AHP to determine the weightage of importance for the characteristics qualities of houses. The gathered information using AHP and Pairwise Comparison Scale will then subsequently entered into the SPSS Version 22 software in generating the median score to be used as the basis for determination of weightage of importance. This step was necessary for achieving the first outlined objective of the research.

The research conducted incorporates the eight main characteristics houses characteristic qualities, and the amount of data will be further analysed by the researcher. The calculation through AHP will then be conducted through the Algebra Matrix score for final results and further analysis. The AHP software being used also gives room for the researcher to produce and tabulate graphs and charts to further visualize the characteristics of houses. From the figure 1 , the overall process and the theoretical framework tabulated by the researcher was shown for easier reference. These were needed for readers to gain comprehension and understanding of the methodology conducted, and the upcoming results for discussion purposes.

\subsubsection{GIS/Observation Forms}

The sampled area in the Klang district consists of ten residential areas, and five houses from each residential areas will be observed through observation forms and also informal 
interviews with the occupants. For this purpose, a total number of 50 observation forms were produced and prepared. The eight elements of functionality, presentation, environment, amenities, community, management, location and access were further elaborated by the researcher with house occupants for their understanding.

The observation survey will later be a combination of results from the questionnaire survey conducted earlier incorporating the elements of AHP. Both questionnaire survey and observation forms totalled at some 50 , and their analysis and results will then form the weightage of the importance of the sampled houses. Through this, the first objective of producing the weightage of the house characteristics qualities will be achieved. The observation survey conducted by the researcher also runs parallel with questionnaire survey distributed and conducted with the respondents in the residential area. The researcher also personally conducts both the questionnaire survey distribution and the observation form survey as to minimise the number of errors that may occur through the help enumerators. This was also due to the fact of lacking of budgetary means from the researcher. From the data collection process, several limitation and constraints were encountered and acknowledged such were the unwillingness of occupants to cooperate, and security guards limiting access to the researcher into residential areas.

Both surveys were conducted together to minimise the time taken and to reduce the workload that the researcher has to bear in going to the same research area to conduct a different survey than the initial questionnaire survey. Information relating to the elements of location characteristics of the houses were conducted through network analysis method through the application of GIS. The GIS was needed to be implemented as it is a suitable application the portray information relating to distances and radius that were not available through the conventional data collection process. The GIS application implemented in this research helps in producing accurate and reliable distance measurement and orientation as compared to measurements in physical maps. Utilizing Geo-spatial information with maps that have satellite coverage up to $100 \mathrm{~mm}$ accuracy nevertheless were today's norms and needs for advance research for distance measurement (Noor, Asmawi, \& Abdullah, 2015). From this condition, the researcher was now able to fulfil the observation forms to be later combined with questionnaire survey and generating the weightage of the importance of the houses.

\subsubsection{Regression Analysis}

Based on discussion with experts in statistics, the best way to achieve the second objective of the research was through the help and application of Regression Analysis into the study. The second objective of the research was to measure the significant relationship between house characteristics qualities and houses prices and the Regression Analysis can portray this and points out variables with significant results. Through the high amount of independent variables, or latent variables, their relationship through the high number of variables can produce the best estimate of relationship results to be tested for validity (Hoyle, 2014). The usage of regression analysis in the research will include all the outlined characteristics qualities earlier as independent variables, and the price of houses will be the dependent variable.

To incorporate the Regression Analysis, the researcher acknowledges that Regression 
Analysis was a prediction method, but considering on the number of independent variables contained in this research, the usage of the method outweighs other forms of relationship analysis method. The predictions produced will take consideration on the number of samples that the researcher has obtained, which was about 50 houses and respondents, and the number of independent and dependent variable outlined. The work process for regression analysis also has to accomplish several assumptions first such were normality, linear relationship between independent and dependent variables, and homoscedasticity (Walker \& Maddan, 2009). The researcher nonetheless will produce the results of regression with these assumptions satisfied already for more rooms for discussion in this research paper.

Table 1: Research Method and Sampling

\begin{tabular}{|c|c|c|c|}
\hline $\begin{array}{l}\text { Stage of } \\
\text { Research }\end{array}$ & Research Objective & $\begin{array}{l}\text { Research Methods \& Types of } \\
\text { Data }\end{array}$ & Selection of Sample \\
\hline Stage 1 & $\begin{array}{l}\text { 1. To produce the } \\
\text { weightage of the house } \\
\text { characteristics qualities }\end{array}$ & $\begin{array}{l}\text { Quantitative Data } \\
\text { Weightage of Importance: } \\
\text { Instrument: } \\
\text { - Questionnaire Survey } \\
\text { Method: } \\
\text { - Analytical Hierarchy } \\
\quad \text { Process (AHP) } \\
\text { - Observation Forms } \\
\text { Respondents: } \\
\text { - One respondent per } \\
\text { household } \\
\text { Sample: } \\
\text { Simple Random Sampling } \\
\text { - Ten household per } \\
\text { residential area } \\
\text { - Total } 50 \text { households } \\
\text { involved } \\
\text { Landed Terrace Houses }\end{array}$ & $\begin{array}{cll}\text { Sampling of Houses } & \\
\text { 1. } & \text { Bandar Bukit Raja } \\
\text { 2. } & \text { Taman Klang } \\
\text { 3. } & \text { Utama } & \\
\text { 3. } & \text { Aman Perdana } \\
\text { 4. } & \text { Bandar Bukit } \\
& \text { Tinggi } & \\
\text { 5. } & \text { Bandar Botanic } \\
\text { 6. } & \text { Taman Sentosa } \\
\text { 7. } & \text { Taman Berkeley } \\
\text { 8. } & \text { Bandar Puteri } \\
\text { 9. } & \text { Taman } & \text { Sri } \\
\text { 10. } & \text { Andalas } & \\
\text { 10. } & \text { Taman } \quad \text { Bayu } \\
& \text { Perdana }\end{array}$ \\
\hline Stage 2 & $\begin{array}{lr}2 . \quad \text { To } & \text { measure } \\
\text { significant } & \text { relationship } \\
\text { between } & \text { house } \\
\text { characteristics qualities } \\
\text { and houses prices }\end{array}$ & $\begin{array}{l}\text { Significant Findings: } \\
\text { Instrument: } \\
\text { - } \quad \text { Regression Analysis } \\
\text { - } \quad \text { SPPS Software Version } 22\end{array}$ & $\begin{array}{ll}\text { 1. } & \text { Functionality } \\
\text { 2. } & \text { Presentation, } \\
\text { 3. } & \text { Environment } \\
\text { 4. } & \text { Amenities, } \\
\text { 5. } & \text { Community, } \\
\text { 6. } & \text { Management, } \\
\text { 7. } & \text { Location } \\
\text { 8. } & \text { Access } \\
\text { 9. } & \text { House Prices }\end{array}$ \\
\hline
\end{tabular}

\subsection{Case Study}

For the case study or sampled areas for the research, previous researches were analysed regarding their selection for suitable areas that can bring out the most precise, accurate and wholly represent their views and ideas. This was later adopted as part of the study process by the researcher. Shabana, Ali, Bashir, \& Ali, (2015) has stated that truthful statements must be obtained from the sample area respondent and honest preferences given, particularly to the studied subject. Abdullah, Salleh, \& Sakip, (2012) also states that the studied area must 
be chosen based on the potential to be studied, and specific information to be obtained, rather than preference chosen by the researcher.

Case study selection was a vital part of any research, and especially for this research. Usage of multiple case studies based on previous research on a particular area of studies can be seen as a way to improve research, as well as giving higher validity and authenticity to replicate the research elsewhere (Mulliner et al., 2013).For this research, ten residential areas were selected namely Bandar Bukit Raja, Taman Klang Utama, Aman Perdana, Taman Sentosa, Taman Berkeley, Taman Sri Andalas, Taman Bayu Perdana, Bandar Bukit Tinggi, Bandar Botanic and Bandar Puteri. These ten residential areas were located in the Klang district, under the jurisdiction of the Klang Town District Council. The residential areas chosen has elements of homogeneity in the houses located inside them, as well their uniqueness and different features. From the literature review, each of characteristics quality can be found in these areas and was well suited with the aim and objectives of the research.

\subsection{Results}

\subsection{Weightage of Importance Findings}

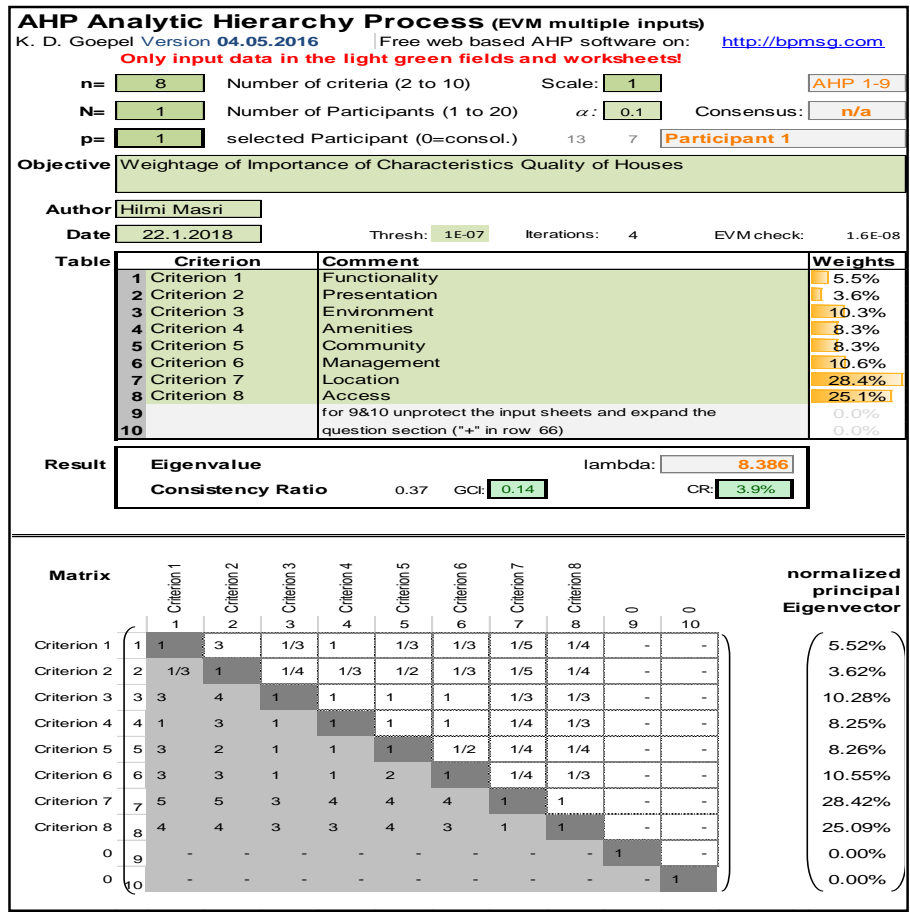

Figure 2: Weightage of Importance of Characteristics Quality of Houses 
From the Figure 2, the researcher has produced the finalised findings obtained for weightage of the importance of the house characteristics. The AHP template also ranks the characteristics accordingly thus making the findings to be shown in more straightforward and more accessible condition (Goepel, 2010). From the findings, this result has been encompassed together with the observation forms finding's to generate overall weightage of importance. The findings results of the characteristics will be discussed further in the next sub-section of the paper.

\subsection{Regression Findings}

From Table 2, the researcher has conducted the linear regression analysis to find out relating to the significant relationship between the variable of functionality and the house prices. From the analysis, the variance relating with the house prices in the sampled research area showed a result of $1.3 \%$ and with a moderate number of $F$ value of 26.75 that correlates with the $p$ value of $0.025\left(R^{2}=0.013, F=26.75, p<0.05\right)$. For the analysis on the variable of functionality itself with the relationship towards house prices $(B=0.163$, $t$-test $=1.134, p<0.05)$, the result showed a moderate significance between the functionality and the house prices in the area. The results predicted a significance that when there was a 1 percent change in the value of functionality, the house prices will increase at the rate of about 0.163 percent in the area.

Table 2: Regression Analysis of Functionality and Prices

\begin{tabular}{|c|c|c|c|}
\hline \multicolumn{4}{|c|}{ Regression Analysis between Functionality and Prices } \\
\hline Functionality & $\begin{array}{l}\text { B } \\
0.163\end{array}$ & $\begin{array}{l}\mathbf{t} \\
1.134\end{array}$ & $\begin{array}{l}\text { Sig. } \\
0.025\end{array}$ \\
\hline$R^{2}$ & 0.013 & & \\
\hline$F$ & 26.75 & & \\
\hline Sig. & 0.025 & & \\
\hline
\end{tabular}

Table 3: Regression Analysis of Presentation and Prices

\begin{tabular}{llll}
\hline \multicolumn{2}{l}{ Regression Analysis between Presentation and Prices } & \\
\hline & $\mathrm{B}$ & $\mathrm{t}$ & Sig. \\
Presentation & 0.128 & 1.019 & 0.258 \\
\hline$R^{2}$ & 0.007 & & \\
$F$ & 11.03 & & \\
Sig. & 0.258 & & \\
\hline
\end{tabular}

From Table 3, the researcher has conducted the linear regression analysis to find out relating to the significance of the relationship between presentation and the house prices. From the analysis, the variance relating with the house prices in the sampled research area showed a result of $0.7 \%$ and with a weak number of $F$ value of 11.03 that correlates with the $p$-value of $0.258\left(R^{2}=0.007, F=11.03, p>0.05\right)$. For the analysis on the variable of the presentation itself with the relationship towards house prices ( $\beta=0.128$, t-test $=1.019, p>0.05)$, the result showed weak indication of significance between the presentation and the house prices in the area. The results predicted a weak significance that when there was a 1 percent change in the value of presentation, the house prices will only increase at the rate of about 0.128 percent in the area. 
Table 4: Regression Analysis of Environment and Prices

\begin{tabular}{|c|c|c|c|}
\hline \multicolumn{4}{|c|}{ Regression Analysis between Environment and Prices } \\
\hline Environment & $\begin{array}{l}\text { B } \\
0.447\end{array}$ & $\begin{array}{l}\mathrm{t} \\
3.413\end{array}$ & $\begin{array}{l}\text { Sig. } \\
0.000\end{array}$ \\
\hline$R^{2}$ & 0.147 & & \\
\hline$F$ & 47.80 & & \\
\hline Sig. & 0.000 & & \\
\hline
\end{tabular}

From Table 4, the researcher has conducted the linear regression analysis to find out relating to the significant relationship between environment and the house prices. From the analysis, the variance relating with the house prices in the sampled research area showed a result of $14.7 \%$ and with the number of $F$ value of 47.80 that correlates with the $p$-value of $0.000\left(R^{2}=0.147, F=47.80, p<0.05\right)$. For the analysis on the variable of the environment itself with the relationship towards house prices ( $\beta=0.447$, t-test $=3.413, p<0.05)$, the result showed a strong indication of significance between the environment and the house prices in the area. The results predicted a significance that when there was a 1 percent change in the value of the environment, the house prices will increase at the rate of about 0.447 percent in the area.

Table 5: Regression Analysis of Amenities and Prices

\begin{tabular}{|c|c|c|c|}
\hline \multicolumn{4}{|c|}{ Regression Analysis between Amenities and Prices } \\
\hline Amenities & $\begin{array}{l}\text { B } \\
0.287\end{array}$ & $\begin{array}{l}\mathbf{t} \\
2.970\end{array}$ & $\begin{array}{l}\text { Sig. } \\
0.001\end{array}$ \\
\hline$R^{2}$ & 0.074 & & \\
\hline$F$ & 31.63 & & \\
\hline Sig. & 0.001 & & \\
\hline
\end{tabular}

From Table 5, the researcher has conducted the linear regression analysis to find out relating to the significant relationship between amenities and the house prices. From the analysis, the variance relating with the house prices in the sampled research area showed a result of $7.4 \%$ and with the number of $F$ value of 31.63 that correlates with the $p$-value of $0.001\left(R^{2}=0.074, F=31.63, p<0.05\right)$. For the analysis on the variable of amenities itself with the relationship towards house prices $(B=0.287$, t-test $=2.970, p<0.05)$, the result showed a strong indication of significance between the amenities and the house prices in the area. The results predicted a significance that when there was a 1 percent change in the value of the environment, the house prices will increase at the rate of about 0.287 percent in the area.

Table 6: Regression Analysis of Community and Prices

\begin{tabular}{llll}
\hline \multicolumn{5}{l}{ Regression Analysis between Community and Prices } & \\
\hline & $\mathbf{B}$ & $\mathbf{t}$ & Sig. \\
Community & 0.182 & 1.307 & 0.002 \\
\hline$R^{2}$ & 0.017 & & \\
$F$ & 20.30 & & \\
Sig. & 0.002 & & \\
\hline
\end{tabular}

From Table 6, the researcher has conducted the linear regression analysis to find out relating to the significant relationship between the community and the house prices. From 
the analysis, the variance relating with the house prices in the sampled research area showed a result of $1.7 \%$ and with the number of $F$ value of 20.30 that correlates with the $p$-value of $0.002\left(R^{2}=0.017, F=20.30, p<0.05\right)$. For the analysis on the variable of the community itself with the relationship towards house prices $(\beta=0.182$, t-test $=1.307, p<0.05)$, the result showed a strong indication of significance between the community and the house prices in the area. The results predicted a significance that when there was a 1 percent change in the value of community, the house prices will increase at the rate of about 0.182 percent in the area.

Table 7: Regression Analysis of Management and Prices

\begin{tabular}{llcl}
\hline \multicolumn{4}{l}{ Regression Analysis between Management and Prices } \\
\hline & $\mathbf{B}$ & $\mathbf{t}$ & Sig. \\
Management & 0.423 & 2.430 & 0.000 \\
\hline$R^{2}$ & 0.122 & & \\
$F$ & 36.05 & & \\
Sig. & 0.000 & & \\
\hline
\end{tabular}

FromTtable 7, the researcher has conducted the linear regression analysis to find out relating to the significant relationship between management and the house prices. From the analysis, the variance relating with the house prices in the sampled research area showed a result of $12.2 \%$ and with the number of $F$ value of 36.05 that correlates with the $p$-value of $0.000\left(R^{2}=0.122, F=36.05, p<0.05\right)$. For the analysis on the variable of management itself with the relationship towards house prices ( $B=0.423$, t-test $=2.430, p<0.05)$, the result showed a strong indication of significance between the management and the house prices in the area. The results predicted a significance that when there was a 1 percent change in the value of management, the house prices will increase at the rate of about 0.423 percent in the area.

Table 8: Regression Analysis of Location and Prices

\begin{tabular}{|c|c|c|c|}
\hline \multicolumn{4}{|c|}{ Regression Analysis between Location and Prices } \\
\hline Location & $\begin{array}{l}\text { B } \\
0.721\end{array}$ & $\begin{array}{l}\mathbf{t} \\
3.730\end{array}$ & $\begin{array}{l}\text { Sig. } \\
0.000\end{array}$ \\
\hline$R^{2}$ & 0.379 & & \\
\hline$F$ & 81.25 & & \\
\hline Sig. & 0.000 & & \\
\hline
\end{tabular}

From Table 8, the researcher has conducted the linear regression analysis to find out relating to the significant relationship between location and the house prices. From the analysis, the variance relating with the house prices in the sampled research area showed the highest result of $37.9 \%$ and with the number of $F$ value of 81.25 that correlates with the $p$-value of $0.000\left(R^{2}=0.379, F=81.25, p<0.05\right)$. For the analysis on the variable of the location itself with the relationship towards house prices $(B=0.721$, t-test $=3.730, p<0.05)$, the result showed the strongest indication of significance between the location and the house prices in the area. The results predicted a significance that when there was a 1 percent change in the value of location, the house prices will increase at the rate of about 0.721 percent in the area. 
Table 9: Regression Analysis of Access and Prices

\begin{tabular}{|c|c|c|c|}
\hline \multicolumn{4}{|c|}{ Regression Analysis between Access and Prices } \\
\hline & B & $\mathrm{t}$ & Sig. \\
\hline Access & 0.532 & 3.517 & 0.000 \\
\hline$R^{2}$ & 0.325 & & \\
\hline$F$ & 67.32 & & \\
\hline Sig. & 0.000 & & \\
\hline
\end{tabular}

From Table 9, the researcher has conducted the linear regression analysis to find out relating to the significant relationship between access and the house prices. From the analysis, the variance relating with the house prices in the sampled research area showed the result of $32.5 \%$ and with the number of $F$ value of 67.32 that correlates with the $p$-value of $0.000\left(R^{2}=0.325, F=67.32, p<0.05\right)$. For the analysis on the variable of access itself with the relationship towards house prices $(B=0.532$, $t$-test $=3.517, p<0.05)$, the result showed a strong indication of significance between the access and the house prices in the area. The results predicted a significance that when there was a 1 percent change in the value of access, the house prices will increase at the rate of about 0.532 percent in the area.

\subsection{Discussion}

\subsection{Weightage of Importance Discussion and Analysis}

The characteristics being measured for weightage were functionality, presentation, environment, amenities, community, management, location and access. From the finalized findings in figure 2, it can be seen that the highest weightage for the characteristics qualities was the location aspect. This was shown through the highest percentage of $28.4 \%$. The second highest ranking provided from the findings showed that access managed to get $25.1 \%$ while the third highest weightage was management with $10.6 \%$. The next characteristics were amenities and community with $8.3 \%$ each respectively. For the second lowest ranking, it was functionality with $5.5 \%$ and the lowest ranking was the functionality with a value of $3.6 \%$ respectively. For reference, the highest and lowest ranking difference was a figure of $24.8 \%$.

From the figure 2 also, it showed that location was the highest characteristics deemed to have most weightage from the views of the sampled respondents combined with the observation forms. This can be attributed to the popular perception that location was important to houses, but through the weightage, it has provided the empirical measurement needed in this research. Location was important as it involves the daily travel of occupants to workplace or places of interest.

The second highest weightage characteristics from findings showed that the results prefer towards access factor and obtaining $25.1 \%$ value. The result showed that accessibility, especially by superior transport options such as personal vehicle, were preferred In the Malaysian context, the usage of the personal vehicle was much higher as compared to other developing countries (Asgari, Zaman, \& Jin, 2017). 
The third weightage characteristics obtained from the findings evidence that management obtained $10.6 \%$. As more and more residential development have higher security level as gated and guarded neighbourhood, this condition was weighted higher by occupants and observation made by the researcher. Higher preference towards management also showed that occupants want more living space with privacy, and private living spaces must also be accompanied by clean and properly maintained housing areas.

The eight and last ranked characteristics showed by the findings result was the presentation aspect with $3.6 \%$. This condition was almost similar to functionality aspect as it concerns with the knowledge and exposure of occupants towards their own houses. The preference for the presentation being the lowest ranked also showed that upon occupants enter and settle in the houses, these characteristics were not needed and didn't have high weightages as compared to the other characteristics. Through the results, the first objective outlined in the research was achieved.

\subsection{Regression Analysis and Discussions}

Based on Table 2, the regression analysis has generated findings that showed there was a moderate significant relationship between functionality and the house prices in the area. This result brings the inference that functionality was does not have a high preference as compared to other characteristics. The occupants expect that functionality quality must be available for their houses, but it does not contribute highly towards the prices of their houses.

For Table 3, the regression analysis has produced the finding that showed there was a weak relationship between presentation and the house prices in the area. This showed that presentation was not significant and yielded the weakest relationship amongst all the variables outlined. The researcher showed that occupants evaluate houses more on paper as compared with the actual presentation characteristics.

Table 4 showed the regression analysis findings showed there was a significant relationship between environment and the house prices in the area. Decision-making process to purchase houses has a relationship on this, and prospective buyer also looks at the factor of the external environment of the houses. This can be related that the neighbourhood itself contains the characteristics suitable for a long-term living of the buyer of the house together with their families. A residential area with environmentally quality characteristics helped gives much potential appreciation towards house prices and was predicted by the regression analysis.

For Table 5, it showed there was a significant relationship between amenities and the house prices in the area. It was an essential living condition for the occupants, and their relationship was shown as significant and can influence the house prices. Provisions of a good residential can give the needed sense of belonging, higher quality of live and also good quality residential environment for occupants.

In Table 6, it showed there was also a significant relationship between the community and the house prices in the area. This characteristic was shown in the previous literature review as less covered by previous researchers relating to quality level and the relationship with house prices. Community aspect and cohesion not only brings higher quality on social life but gives affect towards house prices in the area. From the findings, it showed the result 
of higher value towards social interaction amongst occupants and neighbours surrounding their houses.

Table 7 results of the regression analysis produced findings that portrays a significant relationship between management and the house prices in the area. Management as a whole was needed by all property involving houses, and it was not a specific condition for stratified houses only, but also affects landed houses. Occupants in landed houses should be receiving vital services such were the rubbish collection, maintenance services and others to have a higher quality of life. One of the important element was security that can also contribute towards the quality level of residential areas. Higher security from good management characteristic can protect occupants when they were at home or out to work and not risking their houses and belonging to theft and burglary.

In Table 8, the regression analysis has produced the finding that showed there was a strong significant relationship between location and the house prices in the area. As in the literature review and previous research, location was a key element for houses and have high effects on the house prices. Occupants prefer houses with the location that gives them comfort to travel and located in the matured township and urban areas. This was supported by Masri, Nawawi, \& Sipan, (2016) that states locational aspect in urban areas were more preferred and became a catalyst to migrate from rural areas.

Lastly, for Table 9, the regression analysis has the findings showing there was a strong significant relationship between access and the house prices in the area. Access was another variable that was highly valued by house occupants and constitute high relations towards effect on house prices. The access element showed that accessibility of occupants to move around their residential areas were needed, and preference was that accessibility to get to their own houses were not obstructed. In summary, all the outlined results and discussion showed strong, moderate or weak significant results thus achieving the second objective of the research that was to measure the significant relationship between house characteristics qualities and houses prices. Through both objectives completion, the research aim to come up with significant results of the relationship between house qualities and house prices was also satisfied.

\subsection{Conclusion}

This final topic will summarize from the main findings, and the discussions conducted relating to the research. The work conducted in the research was necessary for the aim and objectives outlined in the research can be achieved. From the findings also, the researcher recommends that these significant characteristics qualities of houses were emphasized by stakeholders in offering houses that affect house prices. It is expected that this recommendation will help with future house buyers in making a better decision relating to housing conditions and improve the property market. This was needed as to offering of future houses with a significant relationship with prices offered.

The researcher has shown through the research process that they were several scopes of further research that can be conducted in the future resulting from this paper. Amongst 
them was the replication of the research process towards other major cities and townships in Malaysia with bigger urban areas focused such were Kuala Lumpur, Penang and Kuantan and also with more elaborate characteristics to be included.

\section{Acknowledgement}

The researcher gives thanks to the other authors that were involved in producing this paper. The researcher also wants to express gratitude to his wife and children for giving the support in completing this study. Lastly, without the financial assistance from KPTM-MyBrain15, this whole study may not be completed. Thank you.

\section{References}

Abdullah, A., Salleh, M. N. M., \& Sakip, S. R. M. (2012). Fear of Crime in Gated and Non-gated Residential Areas. Procedia - Social and Behavioral Sciences, 35(December 2011), 63-69. http://doi.org/10.1016/j.sbspro.2012.02.063

Abdullah, L., Jaafar, S., \& Taib, I. (2013). Ranking of Human Capital Indicators Using Analytic Hierarchy Process. Procedia - Social and Behavioral Sciences, 107(2007), 22-28. http://doi.org/10.1016/j.sbspro.2013.12.394

Adeoye, D. O. (2016). Challenges of Urban Housing Quality: Insights and Experiences of Akure, Nigeria. Procedia - Social and Behavioral Sciences, 216(October 2015), 260-268. http://doi.org/10.1016/j.sbspro.2015.12.036

Agarwal, P. K., Patil, P. K., \& Mehar, R. (2013). A Methodology for Ranking Road Safety Hazardous Locations Using Analytical Hierarchy Process. Procedia - Social and Behavioral Sciences, 104, 1030-1037. http://doi.org/10.1016/j.sbspro.2013.11.198

Asgari, H., Zaman, N., \& Jin, X. (2017). Understanding Immigrants' Mode Choice behaviour in Florida: Analysis of Neighborhood Effects and Cultural Assimilation. Transportation Research Procedia, 25, 3083-3099. http://doi.org/10.1016/j.trpro.2017.05.319

Ball, M. (2015). Housing provision in 21st century Europe. Habitat International, 1-7. http://doi.org/10.1016/j.habitatint.2015.11.024

Dinarvandi, M., Jafari, H., Mohamadi, M., \& Hosseini, A. (2014). Improving the Quality of Service to the Urban Environment for Sustainable Development. Procedia - Social and Behavioral Sciences, 120, 487-495. http://doi.org/10.1016/j.sbspro.2014.02.128

Elshater, A. (2012). New Urbanism Principles versus Urban Design Dimensions towards Behavior Performance Efficiency in Egyptian Neighbourhood Unit. Procedia - Social and Behavioral Sciences, 68, 826-843. http://doi.org/10.1016/j.sbspro.2012.12.270

Erbıyık, H., Özcan, S., \& Karaboğa, K. (2012). Retail Store Location Selection Problem with Multiple Analytical Hierarchy Process of Decision Making an Application in Turkey. Procedia - Social and Behavioral Sciences, 58, 1405-1414. http://doi.org/10.1016/j.sbspro.2012.09.1125

Goepel, A. K. D. (2010). BPMSG AHP Excel Template with multiple Inputs, 1-6.

Ho, D., Chau, K., Yau, Y., Cheung, A., \& Wong, S. (2005). Comparative study of building performance assessment schemes in Hong Kong. The Hong Kong Surveyor, 16(June), 47-58. Retrieved from 
/citations?view_op=view_citation\&continue=/scholar?hl=en\&start=320\&as_sdt=0,5\&scilib=1\&citilm=1\&citation_for _view=n2mStcoAAAAJ:SP6oXDckpogC\&hl=en\&oi=p

Hoyle, R. (2014). Structural Equation Modeling Analysis with Small Samples Using Partial Least Square. SAGE Publications, Inc., (January 1999).

Hui, E. C. M., Chau, C. K., Pun, L., \& Law, M. Y. (2007). Measuring the neighbouring and environmental effects on residential property value: Using spatial weighting matrix. Building and Environment, 42(6), 2333-2343. http://doi.org/10.1016/j.buildenv.2006.05.004

Jucevičius, R., Patašienè, I., \& Patašius, M. (2014). Digital Dimension of Smart City: Critical Analysis. Procedia Social and Behavioral Sciences, 156(April), 146-150. http://doi.org/10.1016/j.sbspro.2014.11.137

Karim, H. A. (2012). Low-Cost Housing Environment: Compromising Quality of Life? Procedia - Social and Behavioral Sciences, 35(December 2011), 44-53. http://doi.org/10.1016/j.sbspro.2012.02.061

Khoiry, M. A., Tawil, N. M., Hamzah, N., Ani, A. I. C., \& Sood, S. (2012). Critical Factors Affecting Double Storey Terrace Houses Prices in Bandar Baru Bangi. Procedia - Social and Behavioral Sciences, 60, 562-566. http://doi.org/10.1016/j.sbspro.2012.09.423

Kim, H. M., Han, S. S., \& O'Connor, K. B. (2015). Foreign housing investment in Seoul: Origin of investors and location of investment. Cities, 42(PB), 212-223. http://doi.org/10.1016/j.cities.2014.07.006

Li, D., Guo, K., You, J., \& Hui, E. C.-M. (2016). Assessing investment value of privately-owned public rental housing projects with multiple options. Habitat International, 53, 8-17. http://doi.org/10.1016/j.habitatint.2015.10.018

Masri, M. H. b M. @, Nawawi, A. H. b, \& Sipan, I. b. (2016). Review of Building, Locational, Neighbourhood Qualities Affecting House Prices in Malaysia. Procedia - Social and Behavioral Sciences, 234, 452-460. http://doi.org/10.1016/j.sbspro.2016.10.263

Masri, M. H. b M. @, Nawawi, A. H., Safian, E. E., \& Saleh, A. F. A. (2017). Characteristic Qualities Impacting Landed House Prices: Better Homes, Better Livelihood. Environment-Behaviour Procedings Journal, (February), 25-27.

Mulliner, E., Smallbone, K., \& Maliene, V. (2013). An assessment of sustainable housing affordability using a multiple criteria decision making method. Omega, 41(2), 270-279. http://doi.org/10.1016/j.omega.2012.05.002

Noor, N. M., Asmawi, M. Z., \& Abdullah, A. (2015). Sustainable Urban Regeneration: GIS and Hedonic Pricing Method in Determining the Value of Green Space in Housing Area. Procedia - Social and Behavioral Sciences, 170, 669-679. http://doi.org/10.1016/j.sbspro.2015.01.069

Omar, K. A., Omar, D., Othman, S., \& Yusoff, Z. M. (2016). The Relationship between Youth Activities and Outdoor Features in Urban Neighbourhood Space. Procedia - Social and Behavioral Sciences, 234, 271-279. http://doi.org/10.1016/j.sbspro.2016.10.243

Panduro, T. E., \& Veie, K. L. (2013). Classification and valuation of urban green spaces-A hedonic house price valuation. Landscape and Urban Planning, 120, 119-128. http://doi.org/10.1016/j.landurbplan.2013.08.009

Pekkonen, M., Du, L., Skon, J. P., Raatikainen, M., \& Haverinen-Shaughnessy, U. (2015). The influence of tenure status on housing satisfaction and indoor environmental quality in Finnish apartment buildings. Building and Environment, 89, 134-140. http://doi.org/10.1016/j.buildenv.2015.02.003

Ramzi, M., Hussain, M., Tukiman, I., \& Zen, I. H. (2014). The Impact of Landscape Design on House Prices and Values in Residential Development in Urban Areas. Procedia - Social and Behavioral Sciences, 10, 316-320. 
http://doi.org/10.1016/j.apcbee.2014.10.059

Safian, E., \& Nawawi, A. H. (2013). Characteristics of Purpose-built Office. Procedia - Social and Behavioral Sciences, 101, 575-584. http://doi.org/10.1016/j.sbspro.2013.07.230

Safian, E., Nawawi, A. H., \& Sipan, I. (2014). Building and Locational Characteristic's Quality of Purpose-Built Office and their Relationship with Rentals. MPRA, 64908(61160).

Saleh, A. F. A., Hwa, T. K., \& Majid, R. (2016). Housing Mismatch Model in Suburban Areas. Procedia - Social and Behavioral Sciences, 234, 442-451. http://doi.org/10.1016/j.sbspro.2016.10.262

Saleh, A. F., Hwa, T. K., Ab Majid, R., \& Mohamad@Masri, M. H. (2017). Attributes of Housing Mismatch Framework in Urban Areas. Environment-Behaviour Proceedings Journal, (February), 25-27. http://doi.org/10.21834/ebpj.v2i5.701

Shabana, Ali, G., Bashir, M. K., \& Ali, H. (2015). Housing valuation of different towns using the hedonic model: A case of Faisalabad city, Pakistan. Habitat International, 50, 240-249. http://doi.org/10.1016/j.habitatint.2015.08.036

Tobergte, D. R., \& Curtis, S. (2013). How you can use AHP to make key business decisions. Journal of Chemical Information and Modeling, 53(9), 1689-1699. http://doi.org/10.1017/CBO9781107415324.004

Walker, J., \& Maddan, S. (2009). Factor analysis, path analysis, and structural equation modeling. Statistics in Criminology and Criminal Justice: Analysis and Interpretation, 325-350.

Zahirovich-herbert, V., \& Gibler, K. M. (2014). The effect of new residential construction on housing prices. Journal of Housing Economics, 26, 1-18. http://doi.org/10.1016/j.jhe.2014.06.003 